\title{
A novel role for 3, 4-dichloropropionanilide (DCPA) in the inhibition of prostate cancer cell migration, proliferation, and hypoxia-inducible factor I alpha expression Bing-Hua Jiang*1,2, Ling-Zhi Liu ${ }^{1,2}$, Rosana Schafer ${ }^{1,2}$, Daniel C Flynn ${ }^{1,2}$ and John B Barnett*1,2
}

Address: ${ }^{1}$ Department of Microbiology, Immunology, and Cell Biology, West Virginia University, Morgantown, West Virginia 26506, USA and 2The Mary Babb Randolph Cancer Center, West Virginia University, Morgantown, West Virginia 26506, USA

Email: Bing-Hua Jiang* - bhjiang@hsc.wvu.edu; Ling-Zhi Liu - lliu@hsc.wvu.edu; Rosana Schafer - rschafer@hsc.wvu.edu; Daniel C Flynn - dflynn@hsc.wvu.edu; John B Barnett* - jbarnett@hsc.wvu.edu

* Corresponding authors

Published: 02 August 2006

BMC Cancer 2006, 6:204 doi:10.1 186/147I-2407-6-204

This article is available from: http://www.biomedcentral.com/I47I-2407/6/204

(c) 2006 jiang et al; licensee BioMed Central Ltd.

This is an Open Access article distributed under the terms of the Creative Commons Attribution License (http://creativecommons.org/licenses/by/2.0), which permits unrestricted use, distribution, and reproduction in any medium, provided the original work is properly cited.

\begin{abstract}
Background: The amide class compound, 3, 4-dichloropropionanilide (DCPA) is known to affect multiple signaling pathways in lymphocyte and macrophage including the inhibition of NF- $\mathrm{kB}$ ability. However, little is known about the effect of DCPA in cancer cells. Hypoxia-inducible factor I (HIFI) regulates the expression of many genes including vascular endothelial growth factor (VEGF), heme oxygenase I, inducible nitric oxide synthase, aldolase, enolase, and lactate dehydrogenase $A$. HIF-I expression is associated with tumorigenesis and angiogenesis.
\end{abstract}

Methods: We used Transwell assay to study cell migration, and used immunoblotting to study specific protein expression in the cells.

Results: In this report, we demonstrate that DCPA inhibited the migration and proliferation of DUI 45 and PC-3 prostate cancer cells induced by serum, insulin, and insulin-like growth factor I (IGF-I). We found that DCPA inhibited HIF-I expression in a subunit-specific manner in these cancer cell lines induced by serum and growth factors, and decreased HIF-I $\alpha$ expression by affecting its protein stability.

Conclusion: DCPA can inhibit prostate cancer cell migration, proliferation, and HIF-I $\alpha$ expression, suggesting that DCPA could be potentially used for therapeutic purpose for prostate cancer in the future.

\section{Background}

The genetic alterations in human cancer are a major focus of cancer research over the past two decades. Many genetic alterations such as activation of oncogenes and inactivation of tumor suppression genes lead to the increased expression of Hypoxia-inducible factor 1 (HIF-1) [1-4].
HIF-1 is a heterodimeric transcription factor composed of HIF- $1 \alpha$ and HIF- $1 \beta$ subunits $[5,6]$. HIF- 1 regulates the expression of many genes including vascular endothelial growth factor (VEGF), heme oxygenase 1, inducible nitric oxide synthase, aldolase, enolase, and lactate dehydrogenase A [7]. HIF-1 activity correlates with tumorigenesis 
and angiogenesis when wild type and HIF-1-deficient cell lines levels were injected into nude mice $[1,8]$. HIF-1 is overexpressed in many human cancers including prostate cancer [9]. HIF-1 expression in prostate cancer cells is induced by growth factors, and inhibited by phosphatidylinositol 3-kinase (PI3K) inhibitors and the tumor suppressor PTEN $[2,10]$.

The amide class compound, DCPA is a dichlorinated ring compound of low molecular weight. Previous investigations on the effects of this compound on lymphocyte and macrophage signaling pathways, reveal that this compound reduces NF- $\kappa \mathrm{B}$ DNA binding ability [11]. This correlates with the down regulation of the production of a number of proinflammatory cytokines, including tumor necrosis factor- $\alpha$, interleukin (IL)-6, IL-1 $\beta$ [11-13] as well as IL-2 [14-17] DCPA also inhibits activation of key components of the Ras pathway [17]. The noted down regulation of the signaling pathways leads us to speculate that DCPA may also affect these pathways in cancer cells in a manner that could be exploited to provide a mode of chemotherapy against these tumors. In this study, we show that DCPA inhibited serum and growth factorinduced cell migration and proliferation, and inhibited HIF-1 expression induced by serum and growth factors in prostate cancer cells. This study indicates that DCPA or its analog may represent a new therapeutic agent for cancer treatment due to its relatively low toxicity.

\section{Methods}

\section{Cell culture}

The human prostate cancer cell line, DU145, was cultured in minimum essential medium (MEM) with Earle's salts and glutamine (Gibco BRL, Grant Island, NY), supplemented with 10\% fetal bovine serum (FBS) (Hyclone) and 3\% chicken serum (Gibco BRL, Grant Island, NY). The human prostate cancer cell line, PC-3, was cultured in F-12K nutrient mixture (Kaighn's modification) (Gibco BRL), supplemented with $10 \%$ FBS and $1 \%$ chicken serum. The cells were incubated at $37^{\circ} \mathrm{C}$ in $5 \% \mathrm{CO}_{2}$ incubator.

\section{Cell migration assay}

The DU145 and PC-3 cells were cultured in normal medium overnight, then switched to serum-free MEM medium in the presence or absence of DCPA for $18 \mathrm{~h}$. The cells were harvested in Hanks balanced salt solution with $5 \mathrm{mM}$ EDTA and $25 \mathrm{mM}$ HEPES, pH 7.2, washed, and resuspended in serum-free medium (SFM). Cell migration was assayed using a polystyrene Transwell plate (Corning Costar, Cambridge, MA) with $6.5 \mathrm{~mm}$ diameter wells and pore sizes of $8.0 \mu \mathrm{m}$. The wells were coated with $10 \mu \mathrm{g} / \mathrm{ml}$ collagen type 1 (Upstate Biotechnology, Lake Placid, NY) in $1 \times \mathrm{PBS}$ buffer at $4^{\circ} \mathrm{C}$ overnight. The excess collagen was removed from the bottom chambers after the incubation, and replaced with $250 \mu \mathrm{l}$ serum-free medium in the absence or presence of DCPA $(150 \mu \mathrm{M})$ or $10 \%$ FBS. The cells were counted and diluted to 400,000 cells per $\mathrm{ml}$ in SFM, and $250 \mu \mathrm{l}$ of the cells were added to the top of each well. For the DCPA treatment, the cells were incubated with SFM with $150 \mu \mathrm{M}$ DCPA 20 min prior to the addition of 100,000 cells to each well in the presence or absence of $10 \%$ FBS in the bottom chambers, followed by the addition of $10 \%$ serum, $200 \mathrm{nM}$ insulin, or $2 \mathrm{nM}$ insulin-like growth factor I (IGF-I) for $6 \mathrm{~h}$. The wells were incubated at $37^{\circ} \mathrm{C}$ in $5 \% \mathrm{CO}_{2}$ incubator for $6 \mathrm{~h}$. The wells were removed, and the cells on the top of the well were wiped out with a cotton swab, stained with $1 \%$ crystal violet in $0.1 \mathrm{M}$ borate containing 2\% ethanol, $\mathrm{pH} 9.0$ for $20 \mathrm{~min}$. The migrated DU145 and PC-3 cells were rinsed with water, dried, and counted using light microscope with $10 \times$ magnification.

\section{Cell viability assay}

The DU145 and PC-3 cells were seeded at $5 \times 10^{5}$ cells per well in a 24 -well plate, and incubated at $37^{\circ} \mathrm{C}$ in $5 \% \mathrm{CO}_{2}$ incubator in the complete medium for $24 \mathrm{~h}$. Then, the culture medium was removed and replaced with serum-free medium containing DCPA $(25,75$ or $150 \mu \mathrm{M})$ or solvent alone (ETOH). A medium-only control was also included. After the culture in serum-free medium for $24 \mathrm{~h}$, the cells were switched to the medium with $10 \%$ serum for $6 \mathrm{~h}$. The cells were then stained with trypan blue, and counted using standard hematocytometer methods.

\section{Cell proliferation assay}

One day before the assay, DU145 and PC-3 cells were seeded at 100,000 cells per well in a six-well plate and incubated at $37^{\circ} \mathrm{C}$ in $5 \% \mathrm{CO}_{2}$ incubator in the medium as described above. Then the cells were switched to fresh medium containing DCPA $(150 \mu \mathrm{M})$ or solvent alone ( 0 $\mu \mathrm{M}$ DCPA), and the cell number was counted 24,48 , and $72 \mathrm{~h}$ after the treatment using standard hematocytometer methods.

\section{Protein extraction and immunoblotting}

DU145 and PC-3 cells were harvested in cold $1 \times$ PBS and lysed on ice for $30 \mathrm{~min}$ in RIPA buffer $(150 \mathrm{mM} \mathrm{NaCl}, 100$ $\mathrm{mM}$ Tris, $\mathrm{pH} 8,0.1 \%$ SDS, $1 \%$ Triton $\mathrm{X}-100,1 \%$ sodium deoxycholate, $5 \mathrm{mM}$ EDTA and $10 \mathrm{mM} \mathrm{NaF}$ ) supplemented with $1 \mathrm{mM}$ sodium vanadate, $2 \mathrm{mM}$ leupeptin, 2 $\mathrm{mM}$ aprotinin, $1 \mathrm{mM}$ phenylmethylsulfonyl fluoride (PMSF), $1 \mathrm{mM}$ DTT, and $2 \mathrm{mM}$ pepstatin A. The lysates were cleared by centrifugation at 14,000 rpm for $15 \mathrm{~min}$, and the supernatants were collected as total cellular protein extracts. The protein concentration in the extracts was determined using Bio-Rad protein assay reagent (Bio-Rad, Richmond, CA). The protein extracts were separated by SDS-polyacrylamide gel electrophoresis (SDS-PAGE), and transferred to nitrocellulose membranes in $20 \mathrm{mM}$ Tris- 
$\mathrm{HCl}(\mathrm{pH}$ 8.0) containing $150 \mathrm{mM}$ glycine and 20\% (v/v) methanol. Membranes were blocked with 5\% nonfat dry milk in $1 \times$ TBS containing $0.05 \%$ Tween 20 and incubated with antibodies against HIF- $1 \alpha$ and HIF- $1 \beta$ [18]. The protein bands were detected by the incubation with horseradish peroxidase-conjugated antibodies (NEN, Boston, $\mathrm{MA}$ ), and visualized using the enhanced chemiluminescence reagent (NEN).

\section{HIF-I $\alpha$ protein stability analysis}

PC-3 cells were cultured in serum-free medium for $24 \mathrm{~h}$, followed by the incubation with medium containing $10 \%$ fetal bovine serum for $5 \mathrm{~h}$. Then the cells were treated with solvent alone or $150 \mu \mathrm{M}$ DCPA for $1 \mathrm{~h}$, followed by the incubation with $100 \mu \mathrm{M}$ cycloheximide for 0 to $16 \mathrm{~min}$. Cellular lysates were subjected to immunoblotting using antibodies against HIF- $1 \alpha$ and HIF- $1 \beta$. The intensity of HIF- $1 \alpha /$ HIF-1 $\beta$ protein signals was quantified using EagleSight densitometry software (Version 3.21; Stratagene).

\section{Statistical analysis}

The results on DU145 and PC-3 cell migration and proliferation were analyzed statistically using the Student-Newman-Keuls multicomparisons test using SigmaStat Software (SPSS Inc., Chicago, IL).

\section{Results and discussion}

\section{DCPA inhibits prostate cancer cell migration}

The hallmark of tumor cells is their ability to migrate and metastasize. Prostate cancers are known to metastasize in a high percentage of the cases, which is obviously linked to a poor prognosis. Therefore, an agent that could inhibit cell migration with relatively low toxicity would be of benefit, likely as adjunct therapy to more traditional cancer drugs. To determine a potential effect of DCPA on cancer cell migration, cell migration on a collagen substrate was tested using the prostate cancer cell lines, DU145 and PC-3. The results demonstrated that the migration of DU145 cells in medium with serum has two-fold greater than that in serum-free medium (Fig. 1A). DCPA treatment inhibits the cell migration more than two-fold as compared to the solvent control in the presence or absence of serum (Fig. 1A). In PC-3 cells, serum increased the cell migration by $50 \%$ more than the serum-starved cells (Fig. 1B). Similarly, DCPA inhibited the cell migration in the presence and absence of serum. These results suggest that DCPA can inhibit the basal-level and seruminduced cell migration.

To determine if the decreased cell migration was due to decreased cell viability, cell viabilities were determine on separate cultures treated as described above. As shown in Fig. 1C, neither cell line showed any increase in cell death over either the solvent (ETOH) or medium (nil) controls.
Thus, the inhibition of cell migration by DCPA is due to the effect of DCPA on the signaling pathways associated with cell motility and not simply due to increased cell death.

\section{DCPA inhibits cell proliferation}

Unchecked proliferation is also a hallmark of cancer cells that commonly exhibit increased proliferation when compared to normal cells. To examine the effect of DCPA on the proliferation of DU145 and PC-3 cells, we determined the cell proliferation after the treatment for 24,48 , and 72 $\mathrm{h}$. The cell number at $24 \mathrm{~h}$ culture was used as a baseline. In the solvent control, the number of DU145 cells increased by $50 \%$ and $100 \%$ at $48 \mathrm{~h}$ and $72 \mathrm{~h}$, respectively. However, cells cultured in the presence of DCPA did not increase significantly throughout the $72 \mathrm{~h}$ culture period (Fig. 2A). Similarly, DCPA treatment inhibited the proliferation of PC-3 cells (Fig. 2B). PC-3 cells cultured in the presence of solvent control showed 3 -fold increase in cell number over the $72 \mathrm{~h}$ period. However, PC-3 cells cultured in the presence of DCAP showed no net change in cell numbers over the $72 \mathrm{~h}$ period (Fig. 2B). These results suggest that DCPA treatment is sufficient to inhibit the cell proliferation.

\section{DCPA treatment diminishes HIF-I $\alpha$ expression induced by serum}

We previously showed that activation of oncogenes, v-Src and PI3K, increased HIF-1 expression [1,2]. HIF-1 is well established as a transcriptional regulator of VEGF and many other genes involved in tumor growth and angiogenesis $[1,7,8]$. HIF- $1 \alpha$ expression is increased in prostate cancer cells by the addition of serum $[2,10]$. We sought, therefore, to determine whether DCPA affected HIF-1 expression induced by serum. DU145 and PC-3 cells were cultured without serum for $18 \mathrm{~h}$ in the absence or presence of DCPA, then exposed to $10 \%$ serum for $6 \mathrm{~h}$. Serum significantly induced the expression of HIF- $1 \alpha$ in DU145 cells (Fig. 3A), and in PC-3 cells (Fig. 3B). Serum did not increase the levels of HIF-1 $\beta$ expression (Fig. 3 ). The addition of DCPA decreased the induction of HIF- $1 \alpha$ expression by serum. The levels of HIF-1 $\alpha$ expression were diminished to below basal values by $150 \mu \mathrm{M}$ DCPA in DU145 cells (Fig. 3A). The levels of HIF-1 $\beta$ expression were not affected by DCPA. This study indicated that DCPA specifically inhibited HIF- $1 \alpha$ expression induced by serum.

HIF-1 $\alpha$ expression is also up-regulated in response to growth factor signaling $[2,10]$. In order to determine whether DCPA could impede growth factor mediated upregulation of HIF- $1 \alpha$ expression, cells were induced with insulin and IGF-I in the presence or absence of DCPA. The DU145 and PC-3 cells were cultured in the absence of serum for $18 \mathrm{~h}$, followed by the exposure of insulin or 

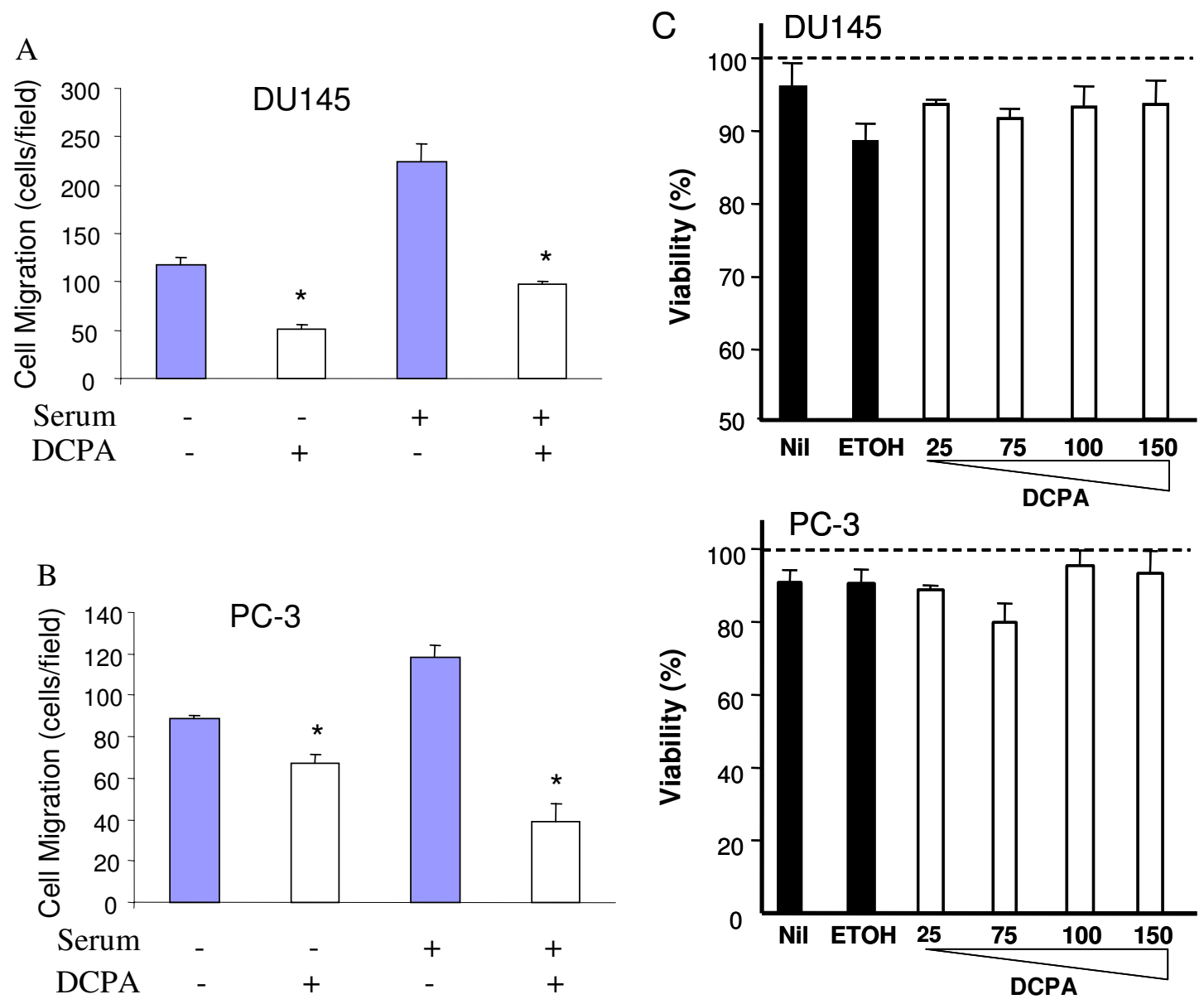

\section{Figure I}

Migration of prostate cancer cells was inhibited by DCPA. Prostate cancer cells, DUI45 (A) and PC-3 (B) cells, were cultured in serum-free medium in the presence $(+)$ or absence $(-)$ of $150 \mu M$ DCPA for $18 \mathrm{~h}$ as indicated. The cell migration assay was performed using Transwell migration chambers coated with $10 \mu \mathrm{g} / \mathrm{ml}$ collagen in the migration buffer with or without $10 \%$ fetal bovine serum for $6 \mathrm{~h}$ at $37^{\circ} \mathrm{C}$ as described in Materials and Methods. The migrated cells were counted, and data were expressed as mean of cell counts from replicate experiments. Bars, SD; * indicates significant difference when compared to cell migration without DCPA $(P<0.01)$. C. Viability of the prostate cancer cells was not affected by DCPA. The cells were cultured in the absence or presence of DCPA for $24 \mathrm{~h}$, and cell viability assay was performed as described in Materials and Methods. The results were expressed as the mean percentage of cells capable of excluding trypan blue. These experiments were repeated at least twice. Bars, SD.

IGF-I for 6 h. HIF-1 $\alpha$ expression in DU145 cells was significantly induced by insulin and IGF-I, and the induced HIF-1 $\alpha$ expression was inhibited by DCPA (Figs. 4A and $4 \mathrm{C})$. But HIF-1 $\beta$ expression was not affected by the addition of insulin and IGF-I or by the presence of DCPA (Figs. 4A and 4C). We also analyzed PC-3 cells for the comparison. HIF-1 $\alpha$ expression in PC-3 cells was also greatly induced by both insulin and IGF-I, and inhibited by the addition of DCPA (Figs. 4B and 4D). In PC-3 cells, the induction of HIF-1 $\alpha$ expression by IGF-I was greater than that by insulin (Figs. 4B and 4D). The expression of HIF$1 \beta$ was not affected in the same experiment. These results suggest that DCPA affects HIF-1 expression in a subunitspecific manner in prostate cancer cells, inhibits HIF- $1 \alpha$ expression induced by growth factors such as insulin and IGF-I, and further suggest that DCPA may be a potential 

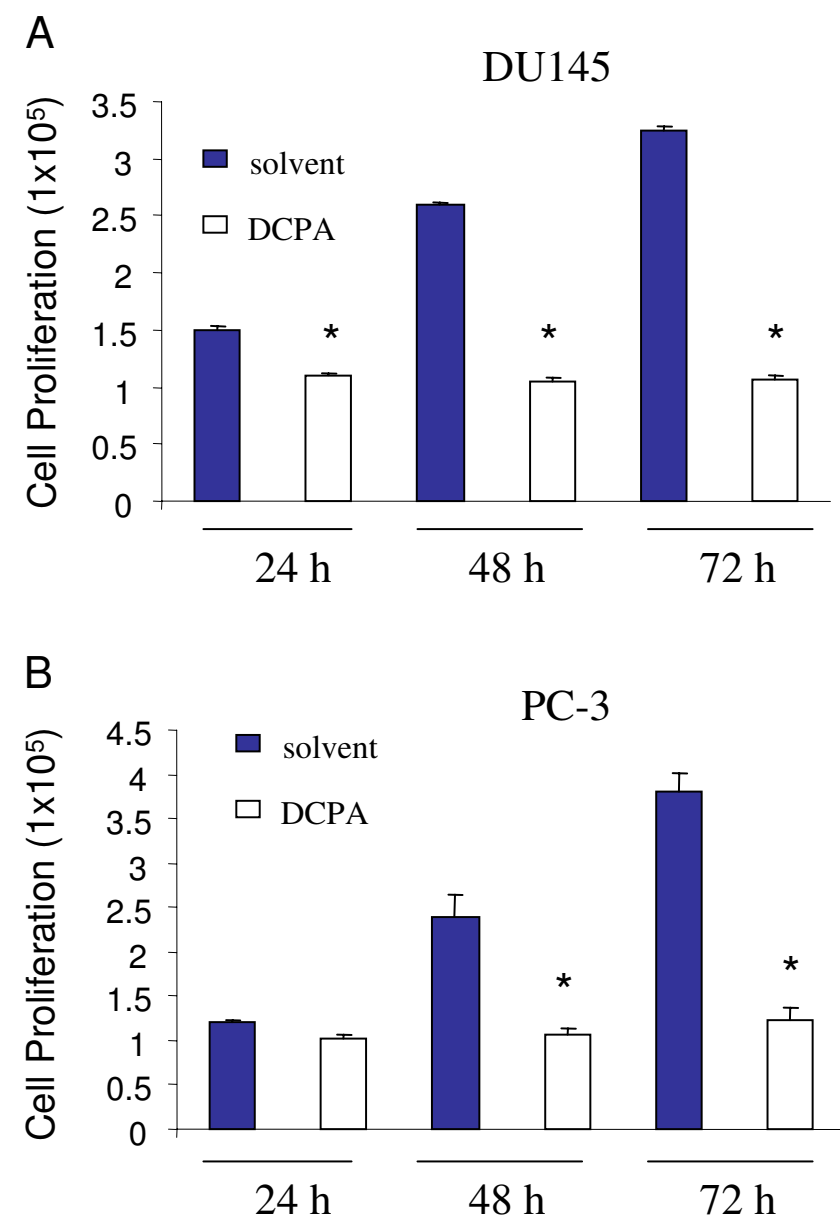

Figure 2

Proliferation of prostate cancer cells was inhibited by DCPA. DUI45 (A) and PC-3 (B) cells were seeded at 100,000 cells per well one day before the addition of DCPA. The cells were incubated in the presence $(+)$ or absence $(-)$ of I $50 \mu \mathrm{M}$ DCPA for 24,48 , and $72 \mathrm{~h}$, as indicated. The cell proliferation assay was performed as described in Materials and Methods. The results are expressed as mean of cell number from replicate experiments. Bars, SD. * indicates significant difference when compared to cell proliferation without DCPA at the same time point $(P<0.0 I)$.

specific molecule to target the growth factor/HIF-1 pathway for cancer therapy.

We demonstrated that DCPA specifically inhibits HIF- $1 \alpha$, but not HIF-1 $\beta$ expression in prostate cancer cells. DCPA may regulate HIF- $1 \alpha$ expression by altering either the stability of HIF- $1 \alpha$ protein, or by inhibiting its mRNA levels. HIF-1 $\alpha$ protein is known to interact with tumor suppressors p53 and von Hippel-Lindau (VHL) protein [19]. Under normal oxygen tension, HIF- $1 \alpha$ is degraded by proteasome degradation pathway. Proteasomal degradation is likewise regulated by $\mathrm{p} 53$ and $\mathrm{VHL}$, which serve to
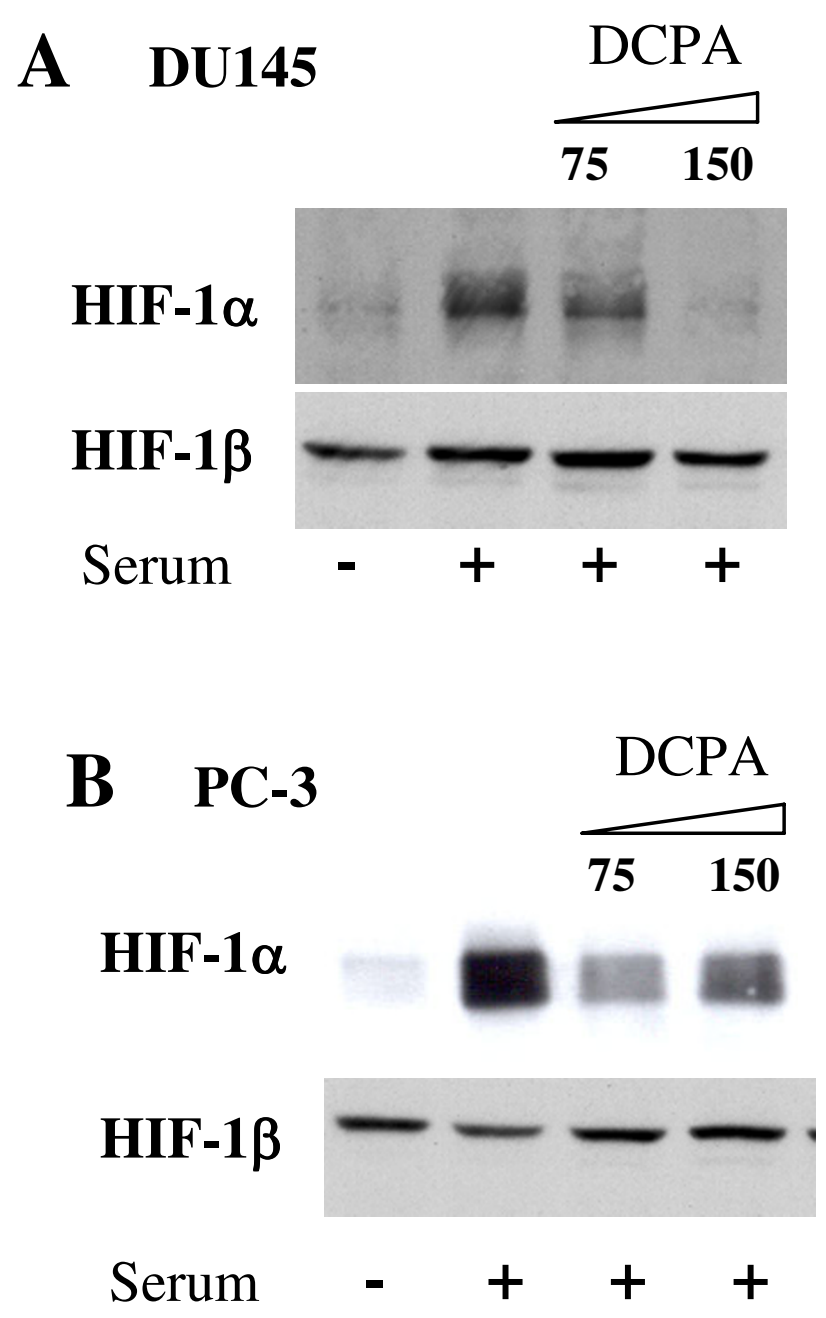

Figure 3

Expression of HIF-I $\alpha$ was specifically induced by the addition of serum, and inhibited by the presence of DCPA. DUI 45

(A) and PC-3 (B) cells were cultured in serum-free MEM basal medium with Earle's salt in 0, 75, or $150 \mu$ M DCPA for $24 \mathrm{~h}$, followed by the incubation with or without $10 \%$ fetal bovine serum for $6 \mathrm{~h}$. Total cellular protein extracts were prepared from these cells, and aliquots of the extracts ( 30 $\mu \mathrm{g})$ were used for the immunoblotting analysis using antibodies against HIF-I $\alpha$ and HIF-I $\beta$.

increase the efficiency of ubiquination of HIF- $1 \alpha$. Conversely, ubiquination of HIF- $1 \alpha$ is decreased by hypoxia, a condition commonly observed in tumors $[20,21]$. To determine whether DCPA treatment affected HIF-1 $\alpha$ protein stability, PC-3 cells were treated with or without DCPA in the presence of $100 \mu \mathrm{M}$ cycloheximide, which inhibits new protein synthesis in the cells. HIF- $1 \alpha$ protein stability was analyzed in the cells. DCPA treatment greatly decreased the HIF- $1 \alpha$ protein stability with $40 \%$ reduction of HIF- $1 \alpha$ protein half-life in the cells (Fig. 5). DCPA 


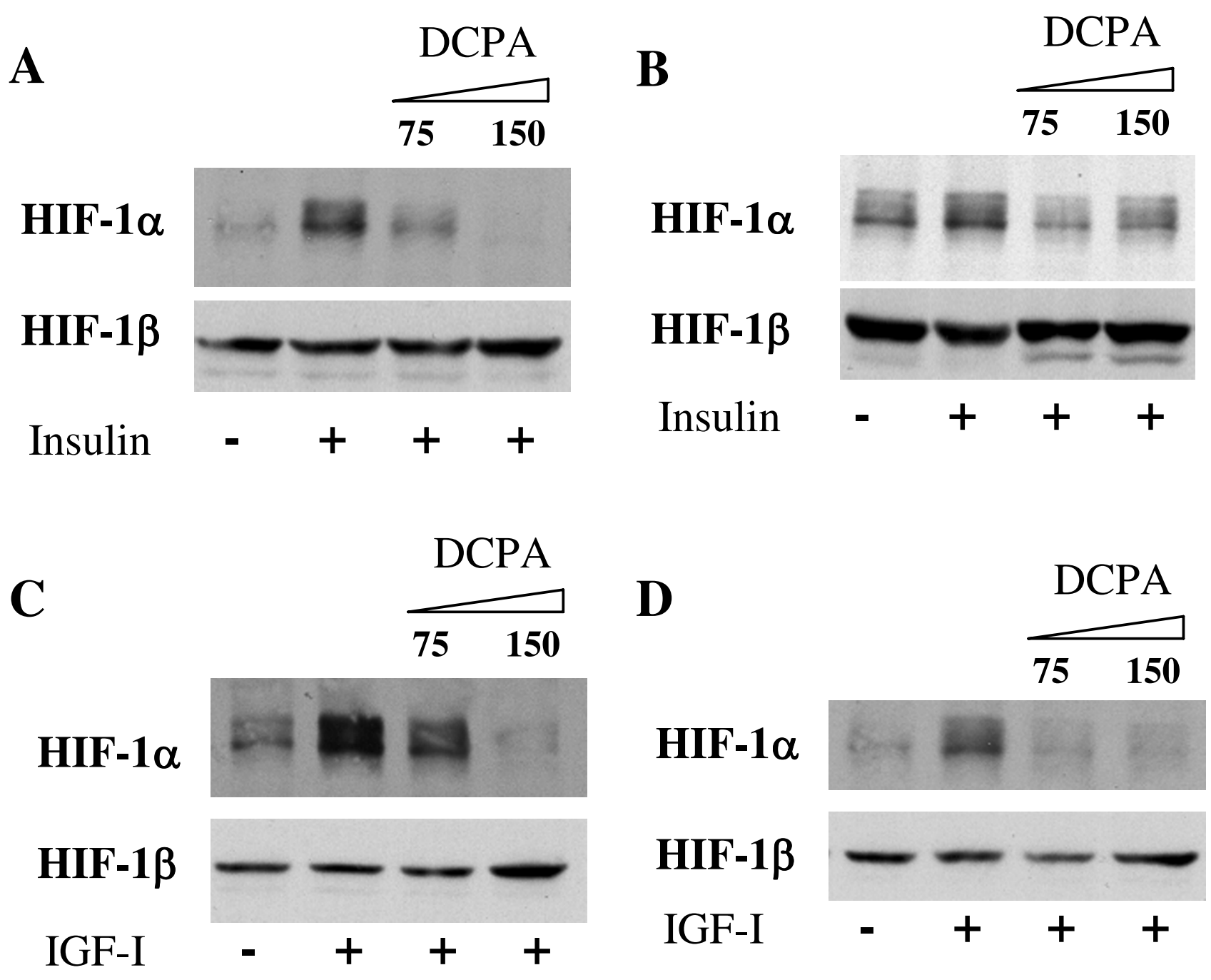

Figure 4

DCPA specifically inhibits expression of HIF-I $\alpha$ induced by insulin and IGF-I. DUI45 (A) and PC-3 (B) cells were cultured in the basal medium without serum in the presence of 0,75 or $150 \mu \mathrm{M}$ DCPA for $24 \mathrm{~h}$, followed by the incubation with (+) or without (-) $200 \mathrm{nM}$ insulin for $6 \mathrm{~h}$. The total cellular proteins were prepared from the cells, and used for the analysis of HIF-I $\alpha$ and HIF-I $\beta$ protein expression as described above. DUI45 (C) and PC-3 (D) cells were cultured in the basal medium without serum as above, followed by the incubation in the presence (+) or absence (-) of 2 nM IGF-I for 6 h. The HIF-I $\alpha$ and HIF-I $\beta$ protein expression from the cells was analyzed by immunoblotting.

treatment did not affect HIF-1 $\alpha$ mRNA level in the cells (data not shown). This result suggests that DCPA treatment may inhibit HIF-1 $\alpha$ protein stability through the proteasomal degradation pathway. To further confirm this hypothesis, we treated the cells with DCPA in the absence or presence of proteasome inhibitor MG132. The presence of MG132 greatly increased HIF-1 $\alpha$ protein levels to much higher levels even in the presence of DCPA than that in the serum treatment alone (Fig. 6), suggesting that DCPA treatment inhibits HIF-1 $\alpha$ protein expression through the proteosomal degradation pathway. Although the signaling pathways that control HIF-1 $\alpha$ expression mediated by DCPA are still unknown, it is possible that HIF- $1 \alpha$ expression is inhibited DCPA via the inhibition of PI3K signaling pathway, which activates AKT [19]. It is known that HIF-1 $\alpha$ expression is inhibited by PI3K inhibitors and the tumor suppressor PTEN $[2,10]$. DCPA may mimic PTEN to inhibit PI3K signaling and thus, HIF- $1 \alpha$ expression. AKT is also known to activate the transcription factor NF- $\kappa \mathrm{B}$ and DCPA down regulates NF- $\kappa \mathrm{B}$ activation [11]. DCPA also selectively inhibits proinflammatory cytokines as well as IL-2 by down regulating transcription [11-16]. Hypoxia condition is commonly observed during tumor growth. To determine whether DCPA treatment 

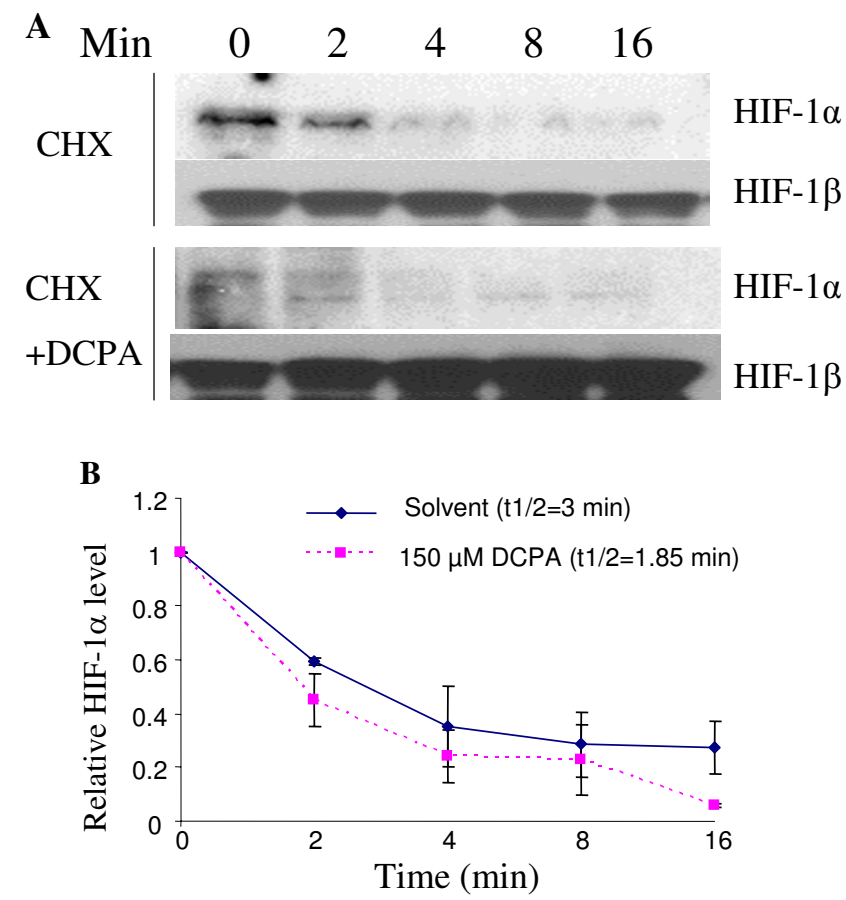

\section{Figure 5}

Effect of DCPA on HIF-I $\alpha$ protein stability. A. PC-3 cells were cultured in serum-free medium for $24 \mathrm{~h}$, followed by the incubation with $10 \%$ fetal bovine serum for $5 \mathrm{~h}$. Then the cells were treated with solvent alone $(\mathrm{CHX}$, top panel) or I $50 \mu$ M DCPA (CHX+DCPA, bottom panel) for I h, followed by the incubation with $100 \mu \mathrm{M}$ cycloheximide for 0 to 16 min. Cellular lysates were subjected to immunoblotting using antibodies against HIF-I $\alpha$ and HIF-I $\beta$. B. The intensity of HIF- I $\alpha$ protein signals obtained above was quantified from three replicate experiments using EagleSight densitometry software (Version 3.2I; Stratagene). The densitometry data were the ratio of HIF-I $\alpha / \mathrm{HIF}-\mathrm{I} \beta$, and normalized to that of the control $(0 \mathrm{~min})$.

affected hypoxia-induced HIF-1 $\alpha$ expression, the cells were cultured in the absence or presence of $1 \% \mathrm{O}_{2}$ condition. DCPA treatment greatly inhibited hypoxia-induced HIF-1 $\alpha$ protein level (Fig. 7), suggesting that DCPA commonly inhibits certain signaling pathways for regulating growth factor- and hypoxia-induced HIF-1 $\alpha$ expression. It is also possible that there may be a connection between inhibition of HIF- $1 \alpha$ expression and inhibition of cell migration, which would be a very interesting topic for the future study. These results indicate that DCPA may inhibit prostate cancer cell migration, proliferation, and HIF- $1 \alpha$ expression through multiple signaling pathways.

\section{Conclusion}

In conclusion, these results demonstrated that DCPA inhibits cell migration, proliferation, and HIF- $1 \alpha$ expression in prostate cancer cells. To further understand the

\section{A DU145}

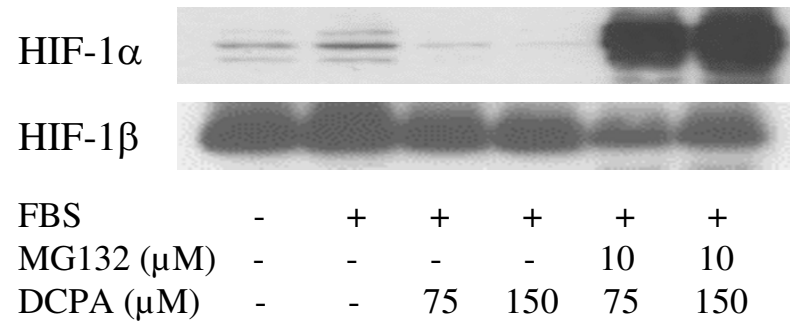

B $\quad \mathrm{PC}-3$

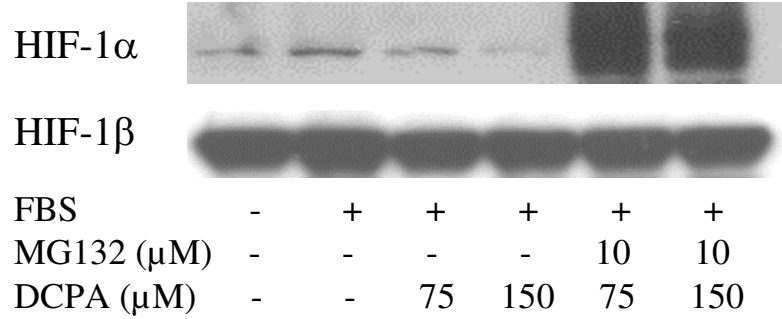

Figure 6

MGI 32 treatment prevented the inhibition of HIF-I $\alpha$ expression by DCPA. DUI45 (A) and PC-3 (B) cells were cultured in serum-free MEM basal medium with Earle's salt in the presence of 0,75 , or I50 $\mu$ M DCPA for $24 \mathrm{~h}$, followed by the treatment with or without $10 \mu \mathrm{M}$ of MG 32 for 30 min. Cells were incubated with or without $10 \%$ fetal bovine serum for $6 \mathrm{~h}$. Total cellular protein extracts were prepared from these cells, and aliquots of the extracts $(30 \mu \mathrm{g})$ were used for the immunoblotting analysis using antibodies against HIF-I $\alpha$ and HIF-I $\beta$.

molecular mechanism of DCPA in decreasing HIF- $1 \alpha$ expression in these cells, we found that 1) DCPA specifically inhibits the induction of HIF- $1 \alpha$ expression by serum, 2) expression of HIF- $1 \beta$ is not altered by the addition of serum or DCPA, 3 ) the effect of DCPA on HIF- $1 \alpha$ is not due to the non-specific effect in the cells, 4) DCPA treatment decreased HIF- $1 \alpha$ expression by affecting its stability through the proteasomal degradation pathway, and 5) DCPA also inhibited hypoxia-induced HIF- $1 \alpha$ expression in human prostate cancer cells.

\section{Abbreviations}

Abbreviations: DCPA, n-3, 4-dichlorophenyl propanamide; FBS, fetal bovine serum; HIF-1, Hypoxia-inducible factor 1; IL, Interleukin; IGF-I, insulin-like growth factor I; MEM, Minimum Essential Medium; PI3K, phosphatidylinositol 3-kinase; SFM, serum-free medium; VEGF, vascular endothelial growth factor. 
A DU145

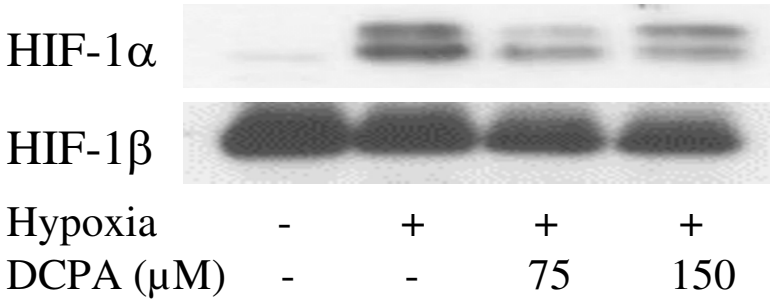

B $\mathrm{PC}-3$

HIF- $1 \alpha$

HIF-1 $\beta$

Hypoxia

DCPA $(\mu \mathrm{M})$

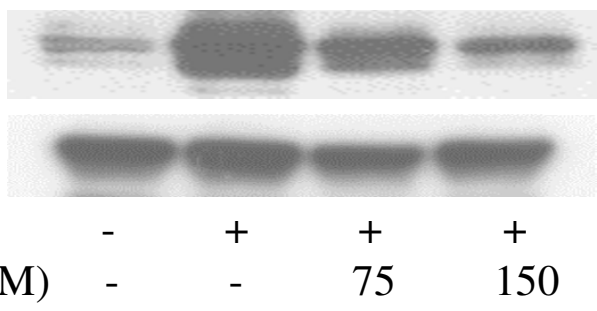

Figure 7

Expression of HIF-I $\alpha$ was specifically induced by hypoxia, and inhibited by the treatment of DCPA. DUI45 (A) and PC3 (B) cells were cultured in complete medium in the presence of 0,75 , or $150 \mu \mathrm{M}$ DCPA for $24 \mathrm{~h}$, followed by the incubation with $20 \%$ or $1 \% \mathrm{O}_{2}$ (hypoxia) for $6 \mathrm{~h}$. Total cellular protein extracts were prepared from these cells, and aliquots of the extracts were used for the immunoblotting analysis.

\section{Competing interests}

The author(s) declare that they have no competing interests.

\section{Authors' contributions}

BHJ performed initial experiments in this study and the overall supervision of the project, and drafted the manuscript; LZL acquired the data for Figs. 5, 6, 7; RS and DCF participated in the design of the study and manuscript preparation; and JBB participated in the design of the study, data interpretation and manuscript preparation. All authors read and approved the final version of the manuscript.

\section{Acknowledgements}

This study was supported by NIH Grants ES075 I2, ESO I I I I, CA I09460; and American Cancer Society Research Scholar Grant 04-076-0I-TBE. We are grateful to Zongxian Cao, Jenny Z. Zheng, Linda Corum, and Cheryl Walton for their technical assistance.

\section{References}

I. Jiang BH, Agani F, Passaniti A, Semenza GL: V-SRC induces expression of hypoxia-inducible factor I (HIF-I) and transcription of genes encoding vascular endothelial growth factor and enolase I: involvement of HIF-I in tumor progression. Cancer Res 1997, 57:5328-5335.

2. Jiang BH, Rue E, Wang GL, Roe R, Semenza GL: Dimerization, DNA binding, and transactivation properties of hypoxiainducible factor I. J Biol Chem 1996, 27I: I 777।-I7778.

3. Semenza GL: HIF-I, O2, and the 3 PHDs: How Animal Cells Signal Hypoxia to the Nucleus. Cell 200I, 107:I-3.

4. Zhong H, De Marzo AM, Laughner E, Lim M, Hilton DA, Zagzag D, Buechler P, Isaacs WB, Semenza GL, Simons JW: Overexpression of hypoxia-inducible factor I alpha in common human cancers and their metastases. Cancer Res 1999, 59:5830-5835.

5. Jiang BH, Jiang G, Zheng JZ, Lu Z, Hunter T, Vogt PK: Phosphatidylinositol 3-kinase signaling controls levels of hypoxia-inducible factor I. Cell Growth Differ 200I, I 2:363-369.

6. Frost LW, Neeley YX, Schafer R, Gibson LF, Barnett JB: Propanil inhibits tumor necrosis factor-a production by reducing nuclear levels of the transcription factor, nuclear factor-kappaB in the macrophage cell line, IC-2I. Toxicol Appl Pharmacol 200I, 172:186-193.

7. Xie YC, Schafer R, Barnett JB: The immunomodulatory effects of the herbicide propanil on murine macrophage interleukin-6 and tumor necrosis factor-alpha production. Toxicol Appl Pharmacol 1997, |45:|84-19|.

8. Zhao W, Schafer R, Cuff CF, Gandy J, Barnett JB: Changes in Primary and Secondary Lymphoid Organ T-Cell Subpopulations Resulting from Acute In Vivo Exposure to Propanil. J Toxicol Environmental Health 1995, 46: I7I-I8I.

9. Jiang BH, Semenza GL, Bauer C, Marti HH: Hypoxia-inducible factor I levels vary exponentially over a physiologically relevant range of $\mathrm{O2}$ tension. Am J Physiol 1996, 27I:CI I72-CI I80.

10. Maxwell PH, Dachs GU, Gleadle JM, Nicholls LG, Harris AL, Stratford IJ, Hankinson O, Pugh CW, Ratcliffe PJ: Hypoxia-inducible factorI modulates gene expression in solid tumors and influences both angiogenesis and tumor growth. Proc Natl Acad Sci U S A 1997, 94:8104-8I09.

II. Zhong H, Chiles K, Feldser D, Laughner E, Hanrahan C, Georgescu MM, Simons JW, Semenza GL: Modulation of hypoxia-inducible factor Ialpha expression by the epidermal growth factorl phosphatidylinositol 3-kinase/PTEN/AKT/FRAP pathway in human prostate cancer cells: implications for tumor angiogenesis and therapeutics. Cancer Res 2000, 60:1541-1545.

12. Laughner E, Taghavi P, Chiles K, Mahon PC, Semenza GL: HER2 (neu) signaling increases the rate of hypoxia-inducible factor Ialpha (HIF-Ialpha) synthesis: novel mechanism for HIF-Imediated vascular endothelial growth factor expression. Mol Cell Biol 200I, 21:3995-4004.

13. Huang LE, Gu J, Schau M, Bunn HF: Regulation of hypoxia-inducible factor I alpha is mediated by an O2-dependent degradation domain via the ubiquitin-proteasome pathway. Proc Natl Acad Sci U S A 1998, 95:7987-7992.

14. Salceda S, Caro J: Hypoxia-inducible factor I alpha (HIF-I alpha) protein is rapidly degraded by the ubiquitin-proteasome system under normoxic conditions. Its stabilization by hypoxia depends on redox-induced changes. J Biol Chem 1997, 272:22642-22647.

15. Xie YC, Schafer R, Barnett JB: Inhibitory effect of 3,4-dichloropropionaniline on cytokine production by macrophages is associated with LPS-mediated signal transduction. J Leukoc Biol 1997, 61:745-752.

16. Zhao W, Schafer R, Barnett JB: Cytokine production by C57BI/6 mouse spleen cells is selectively reduced by exposure to propanil. J Toxicol Environ Health 1996, 55: 107-120.

17. Zhao W, Schafer R, Barnett JB: Propanil affects transcriptional and posttranscriptional regulation of IL-2 expression in activated EL-4 cells. Toxicol Appl Pharmacol 1999, 154:153-159.

\section{Pre-publication history}

The pre-publication history for this paper can be accessed here:

http://www.biomedcentral.com/1471-2407/6/204/pre pub 